\title{
HYGIENE OF THE EPILEPTIC SCHOOL CHILD
} BY

WILLIAM T. SHANAHAN, M. D.,1)

Superintendent of Craig Colony, Sonyea, N. Y.

Epilepsy is a disorder which ordinarily only presents to the mind of the average individual a condition constituted of convulsive attacks, either severe or mild in nature, and not as one having as one of its principal symptoms a more or less marked involvement of the mental state, which unfortunately in a great majority of instances is deteriorating in nature, reaching in no inconsiderable percentage a final state of exceedingly marked mental deficiency.

As most of you are no doubt aware, epilepsy is a disorder of early life, the symptoms appearing in over $80 \%$ of all cases previous to 20 years of age, thus afflicting the unfortunate individual during the period of growth and development.

It has long been known that hereditary influences, acting either directly or indirectly, were active in the production of most epilepsies. Careful studies made in connection with the question of the role of heredity in epileptics have shown that, conservatively speaking, from $60 \%$ to $80 \%$ of all epileptics have in their family a taint indicating that in those families there was present a nervous system below the normal in its general makeup and functioning power. In some members of these families this shows itself by the presence of certain types of insanity, while in others alcoholism, criminalistic tendencies, sexual immorality, vagrancy and the like are observed. In children belonging to such families there is needed but very little in the way of injurious influences to so affect

1) Read before International Congress on School Hygiene Buffalo N. Y. Sept. 27 Igr3 by Dr. G. Kirby Collier. 
the central nervous system as to have appear the symptoms of epilepsy with its accompanying mental involvement. What in the ordinary healthy child might be a simple passing illness from which the child would make a perfect recovery would in the predisposed child serve to act as an exciting cause to bring forth the epileptic seizures.

In $10 \%$ of the epileptics there has occurred during birth, or directly after birth, an injury to the brain as the result of hemorrhage. In consequence of this there is a destruction of more or less of the essential brain substance, resulting in a permanent paralysis usually of onehalf of the body and occasionally more extensive. In this class of paralytics there will appear later in the majority, seizures of various kinds, and more or less marked mental deficiency.

During infancy and childhood, as the sequel to, or coincident with, severe digestive disorders and likewise with some of the various infectious diseases of childhood, such as measles, whooping cough, scarlet fever, etc., there may occur an inflammatory process involving the meninges, the membranes covering the brain, and may involve even the brain itself, destroying the essential nerve cells, producing scar tissue, which will later act as an irritant to the delicate nervous system, or in many instances produce both of these changes and as a result a mental defect and seizures sooner or later present themselves. The unfortunate child may also receive from a blow or fall some serious injury to the brain, causing a destruction beyond repair of important structures so that later the phenomena of epilepsy are observed.

I would like to call your attention to the fact, however, that many of the falls and alleged injuries are simply coincidental and not causative in nature.

The various symptoms of epilepsy, or more strictly speaking the epilepsies are only recognized fully by those who have had a considerable experience with this class of unfortunates. 
To those who are engaged in giving instruction to children, the mental state is the one which naturally is of primary importance when considering these children. There is, as has been already mentioned, a permanent mental impairment in the great majority of epileptics; and in addition to this, one will observe from time to time recurring more or less frequently, depending on the individual case, a marked fluctuation of the mental activities, often to such an extent as to interfere materially with their school work. Periods of irascibility, of apparent resistance to study and to the acceptance of instruction, quarreling with schoolmates and not infrequently active delusions, hallucinations and illusions, relating perhaps to the teacher and other pupils in the immediate environment of the individual are observed. Naturally with such a decidedly unstable mentality, the teacher must be constantly on the lookout to steer around the various obstacles, thus presented in the problem of teaching the epileptic child.

A teacher of experience with these children will, after a time, become sufficiently familiar with the various symptoms of the disorder as to be able to recognize at once in many instances the early indication of the approach of one of these periods of acute mental change and thus avoid many difficulties which to the inexperienced would involve not only much loss of time and energy in giving instruction which could not possibly be grasped, but also prevent much unpleasantness and disturbance arising in the school room.

So far as the chronic and pronounced mental failure is concerned, teachers of experience can readily gauge the limitation of the individual child and not attempt to accomplish the impossible, e. g., by trying to teach an imbecilic child whose mental state has stopped developing at the level of a child of six years, subjects which are taught to a child several years older. Proper use of the Binet and other mental tests will assist very much in ascertaining as to the degree of mental retardation or enfeeblement. 
As the result of many years of experience in the treatment of epileptic children in the various special institutions in the many parts of the civilized world there is a concensus of opinion that more stress should be laid on the manual side of training, rather than ordinary scholastic work, although the latter is not to be ignored and in many special cases is in fact to be carried on very much the same as in the normal children.

Of the utmost value in gaining the interest of the unfortunate epileptic children, who in consequence of their disorder have been deprived of school education, is manual work which tends to bring them out of themselves and expose to light many qualities which no one had realized were present in them.

By work in the school garden, preceded by explanatory lantern slide pictures and demonstrations with later the actual work in the garden there is aroused in these children a spirit of competition, responsibility and earnestness to accomplish something, the result of which can be actually demonstrated without difficulty. In the manual work and gymnastics the epileptic can accomplish anything that can be accomplished by the ordinary child, making due allowance of course for the occurrence of seizures and the actual state of the mental processes as to deterioration.

The average epileptic child is ordinarily fairly adept at weaving, clay modeling, working in pottery, iron work, book binding, Sloyd work, leather work, work with raffia, lace making, basketry, making of palmetto hats, printing, embroidery etc., etc. Many epileptics do well in music, to such an extent in fact that good bands and orchestras are organized in special institutions.

In the school work done by the epileptics at Craig Colony, it has been found that no inconsiderable number of these patients have done exceedingly well in the ordinary scholastic branches so that they in fact well hold their own in a comparison made with pupils not thus afflicted. 
It has long been my impression that in schools other than those located in special Institutions, there must be many epileptic children having seizures at infrequent intervals who can and do progress satisfactorily in the regular school work of the particular grade in which they happen to be.

In the matter of reading, many epileptics are handicapped owing to the existence of what is termed plateau-speech as the result of which the normal inflection is absent, or markedly impaired. These symptoms so affect some epileptic children that reading done by them is very monotonous in character.

Some of the teachers who have been engaged in school work at the Craig Colony have given me the impression which they have gained as the result of their work and these I will briefly summarize; First the teacher who has been working with epileptics for some dozen years states that when she first started the work she did not know how the epileptic school child differed from the normal school child and so began her work with the epileptic school children as though they were of a normal makeup. She began her work under the impression that epileptic children are able and anxious to learn. She soon observed that many of them, especially those coming from the larger cities had, in consequence of their affliction, been closely confined to their homes and in consequence had been materially stunted mentally by such a narrow environment. Their knowledge of ordinary general information was exceedingly limited. The facts known to the normal child of their age were entirely absent. It was at once evident that because of this state of affairs giving of instruction pertaining to new facts could not be associated with any previous knowledge gained by observation by the particular child, hence it was more difficult to fix in the memory of the child the new facts which she was endeavoring to teach. She soon learned, however, that with sufficient tact and persistence, the memory could be 
so drilled that it was much strengthened and the knowledge which she was endeavoring to instill could be retained. This particular teacher states that the ordinary school branches, reading, writing, arithmetic, spelling, etc., are as readily mastered by the average epileptic child as by the ordinary normal school child.

Of the several hundred epileptic school children which this teacher has observed she states that perhaps $20 \%$ are deficient in their ability to grasp arithmetic, this difficulty being seemingly due to an impossibility on their part to be able to use figures as does the ordinary child. In such cases after persistent drilling and the use of various devices toward the bringing about of the knowledge of numbers she states that these are unsuccessful in developing what might be looked for, a latent power of grasping the subject in hand.

It must be realized by teachers in instructing the mentally defective, especially the epileptic that as a rule the amount of time spent daily in school work by such children must be less than that required of normal children. In our experience at the Colony it has been found that from $1 \frac{1}{2}$ to 2 hours is the amount of time ordinarily spent. In selected cases, however, there is no doubt but what such children would be able to spend four or five hours in school with much profit. In fact, they could make good progress or the same progress as the average normal school child.

To those working among epileptic school children it has been found that the question of discipline is not as difficult as many would try to have one believe. Those who tend to be difficult upon a fair trial to make amenable to discipline are the exception and not the rule. The average epileptic school child becomes very much interested in his or her work and is pleased apparently to be placed under a kind control and gives evidence of pride as relates to the school work. There seems to be no question but what most of the difficulties which have been complained 
of in regard to the instruction of epileptic children are the result of neglect or, as one teacher expresses it, of over indulgence. The teacher should be firm and strict in the use of her discipline but not harsh or overbearing any more than with the normal child. To a teacher who lacks tact and power to persistently and constantly carry on her work along lines of least resistance as indicated in the individual child there is danger of her being over indulgent with the epileptic child or being unkind in her attitude toward the afflicted one.

I have been told by a teacher of considerable experience with these defectives that it as much more difficult to overcome the mental habits of an epileptic child who has been over indulged than it is to teach one who has simply been neglected.

A boy 15 years of age suffering from infantile paralysis, involving one half of his body, had been the victim of circumstances which existed from the boy being also subjected to epileptic seizures that prevented him from receiving instruction. During his first year in school little progress was noted, but during the beginning of the $2^{\text {nd }}$ year he askeu his teacher if he might try and read a page on the chart, which request was granted and he was soon able to read fairly well in the First Reader. If the teacher of the epileptic child will be patient, tactful, persistent and intelligent in her efforts there will seldom be presented an epileptic child, unless one who is absolutely defective mentally, who cannot make some progress in school work and as already mentioned, in many instances quite satisfactory advancement.

In a recent spelling match held at the Colony between the boys and the girls, it was of interest to note the manner in which these children participated in the contest. They displayed as much, if not more, interest than would be displayed by children of normal mentality and were able on the whole to render results quite comparable with those expected from the normal child. The writing done 
344 W. T. SHANAHAN, HYGIENE OF THE EPILEPTIC SCHOOL CHILD.

by many of these epileptic children when they have the opportunity to gain some experience is just as good as that seen in the ordinary school room.

The fact which cannot be too strongly impressed upon those having these children under their care is that hand in hand with the school work should go the care and supervision of a competent physician to regulate the living conditions of the child. There must be outlined a careful hygienic mode of life to be consistently adhered to so that the child may approach as nearly as possible the normal physical condition thus enabling him to resist to a marked extent often times the effect of certain deleterious influences acting upon his physical makeup. This careful supervision can naturally better be given in a special Institution where the child is under observation during the entire 24 hours than can be given in the ordinary home.

In summarizing the results of school work with epileptic children, the fact should be borne in mind that when an epileptic child has a seizure there is, as a rule, a marked interference with his mental processes, so that it is difficult or impossible for him at such periods to acquire knowledge. Furthermore the knowledge acquired a short time previous to the occurence of a seizure or series of seizures may be entirely blotted out, necessitating the teacher's repeating the instruction given during this entire period.

Ordinarily, however, excluding the occurrence of seizures and giving due weight to the presence of a mental defect the work of instructing epileptic children is much more encouraging as to its results than is often thought for.

I do not wish to go on record as claiming that the average epileptic child may be brought into school work and results obtained which compare absolutely with those of a normal child, but I do maintain that a large percentage of epileptic children carefully selected and under proper conditions can do quite satisfactory school work in the lower scholastic branches, and in most of the manual branches and that a comparatively small percentage of 
epileptics can carry on advanced school work to a very satisfactory degree. From time to time I have seen epileptics well advanced in years who have had their disorder since early childhood and who nevertheless had acquired a University Degree, standing well in their classes during their college work.

I wish to reiterate that the work in the manual branches should receive more attention in proportion than should the ordinary scholastic work with due allowance for the acquiring of the ability to read and write and carry on simple calculations. While persistence, optimism and tact in the efforts of the teacher should be ever in mind in carrying on school work with any class of children, they are especially necessary in conducting work among those who are afflicted with epilepsy, and as a consequence have a retardation of their mental activities and a narrowing of their psychic sphere.

\section{BIBLIOGRAPHIE.}

LIEPMANN, H., Berlin, Prof. Dr. phil. et med., Oberarzt an der städtischen Irrenanstalt Dalldorf. DIE FREIE Selbstbestimmung bei der Wahl des AufenthaltsORTES NACH DEM REICHSGESETZ ÜBER DEN UNTERStÜtzungswohnsitz. Sammlung zwangloser Abhandlungen aus dem Gebiete der Nerven- und Geisteskrankheiten. 1913. X. Band, Heft 5. Verlag von Carl Marhold in Halle a. S.

Innerhalb der Grenzen des Deutschen Reiches hat, ebenso wie das in vielen andern Lăndern Gesetz ist, die engere Heimat gewisse besondere Verpflichtungen, für ihre unterstützungsbedürftigen Bürger zu sorgen.

Ein Erwachsener, der ein Jahr an einem Orte gewohnt hat, gewinnt hier seinen Unterstützungswohnsitz und verliert ihn, wenn er ein Jahr lang abwesend gewesen ist.

In den Făllen, wo ein Geisteskranker seinen Aufenthalt gewechselt hat, ergibt sich aus diesem Gesetze die Frage an 